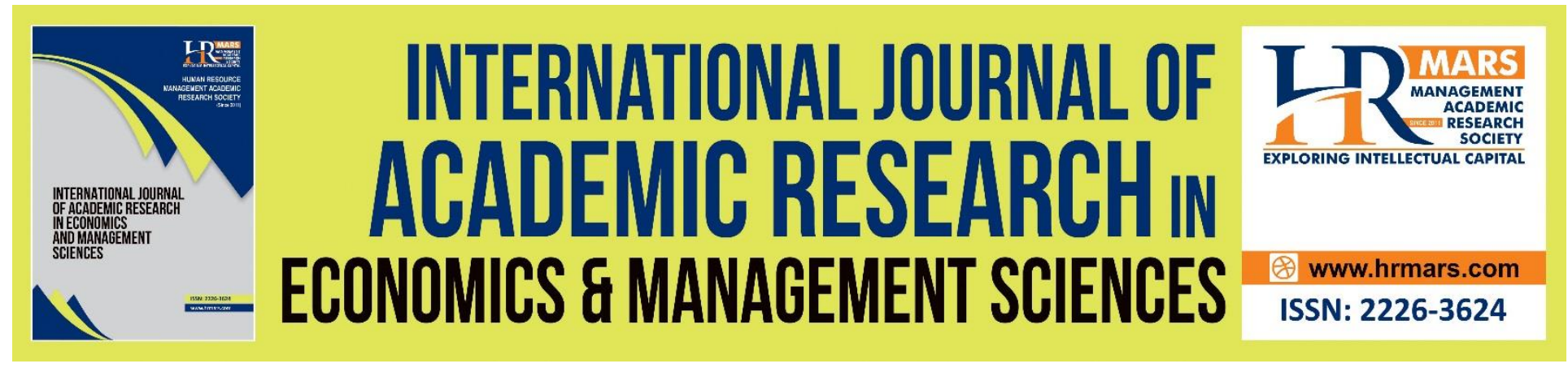

\title{
Assessing the Impact of Corporate Fraud on Firm Performance in Malaysian Tourism Sector: Pre- and During Covid-19 Pandemic
}

\author{
Mohd Taufik Mohd Suffian, Salina Mad, Mohd Zulfikri Abd Rashid, Nor \\ Balkish Zakaria
}

To Link this Article: http://dx.doi.org/10.6007/IJAREMS/v11-i1/11679

DOI:10.6007/IJAREMS/v11-i1/11679

Received: 07 November 2021, Revised: 11 December 2021, Accepted: 26 December 2021

Published Online: 09 January 2022

In-Text Citation: (Suffian et al., 2022)

To Cite this Article: Suffian, M. T. M., Mad, S., Rashid, M. Z. A., \& Zakaria, N. B. (2022). Assessing the Impact of Corporate Fraud on Firm Performance in Malaysian Tourism Sector: Pre- and During Covid-19 Pandemic. International Journal of Academic Research in Economics and Management and Sciences, 11(1), 16-27.

Copyright: (C) 2022 The Author(s)

Published by Human Resource Management Academic Research Society (www.hrmars.com)

This article is published under the Creative Commons Attribution (CC BY 4.0) license. Anyone may reproduce, distribute, translate and create derivative works of this article (for both commercial and non-commercial purposes), subject to full attribution to the original publication and authors. The full terms of this license may be seen at: http://creativecommons.org/licences/by/4.0/legalcode

Vol. 11, No. 1, 2021, Pg. 16 - 27

http://hrmars.com/index.php/pages/detail/IJAREMS

JOURNAL HOMEPAGE

Full Terms \& Conditions of access and use can be found at

http://hrmars.com/index.php/pages/detail/publication-ethics 


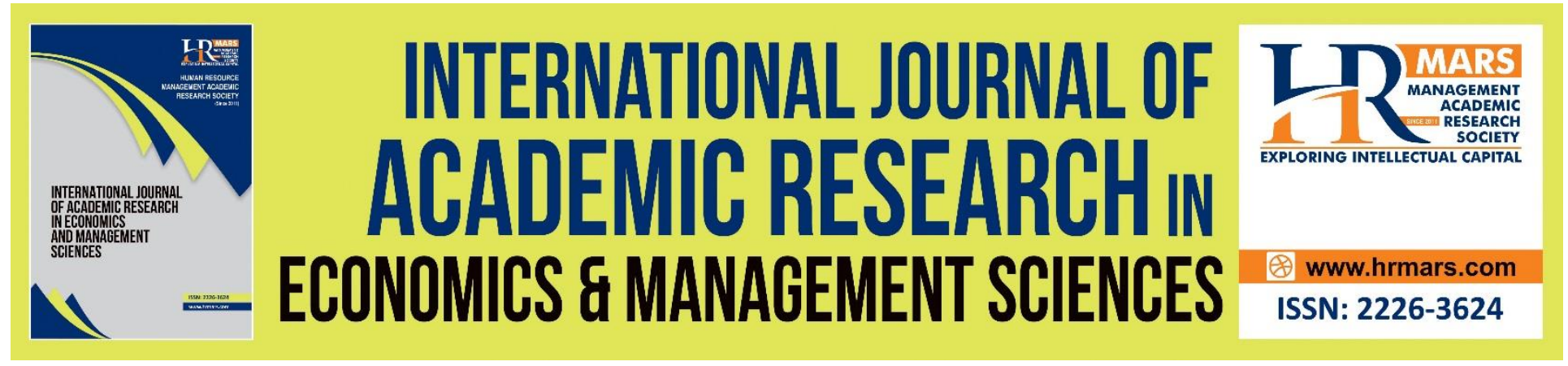

\title{
Assessing the Impact of Corporate Fraud on Firm Performance in Malaysian Tourism Sector: Pre- and During Covid-19 Pandemic
}

\author{
Mohd Taufik Mohd Suffiana, Salina Mada, Mohd Zulfikri Abd \\ Rashid $^{a}$, Nor Balkish Zakariab
}

aUniversiti Teknologi MARA, Tapah, Perak, ${ }^{b}$ Accounting Research Institute, Universiti Teknologi MARA, Shah Alam, Malaysia.

\begin{abstract}
It is vital to examine the performance of listed companies, especially the tourism sector that was believed to be highly impacted during the Covid-19 pandemic. What more if the companies are suspected of corporate fraud. Hence, the purpose of this study is to determine the impact of fraudulent activities on the performance of Malaysian listed tourism companies from 2017 to 2020 based on the sample of 81 firm-year observations. The study period was partitioned to 2017 until 2019 and during in 2020. Beneish model was chosen to represent corporate fraud activity. Based on the pool effect model using STATA Software, regression analysis documents a significant positive impact of corporate fraud on the tourism sector in Malaysia for accounting and market measures. The current findings could be considered as indicators to reduce corporate fraud in improving company performance by management and stakeholders, particularly during the pandemic.
\end{abstract}

Keywords: Corporate Fraud, Firm Performance, Beneish, Tourism Sector, Covid-19 Pandemic

\section{Introduction}

Malaysia is a developing country that has always attracted numerous potential investors due to its promising potential. After the financial crisis of 1997, Malaysia's economic growth rate expand steadily at an average of $5.4 \%$ since 2010 . Despite drastic political changes that occurred in 2018, Malaysia is charging forward as one of the biggest gainers and toughest competitors (Nasir \& Hashim, 2020) and toward becoming a high-income economy by 2024 . Investment has been instrumental in economic growth; hence, firm performance will become the centre of attention in investor decisions.

There are several factors that could affect corporate performance including fraud. The Scandal of 1 Malaysia Development Berhad (1MDB), Petrol One Resources, Sime Darby Berhad and Transmile Group Berhad indicated fraud is not a new issue and become among serious corporate problems that receive greater attention in the mass media, which has demoralized 
investors' confidence (Nasir \& Hashim, 2020). According to KPMG Malaysia Fraud, Bribery and Corruption Survey, the number of fraud cases that occurred in Malaysia increased nearly double over the past three years (KPMG, 2013).

The pandemic Covid-19 that has been hit around the world has contributed to the huge number of losses in the corporate world. Many of these corporate frauds were rooted in financial frauds (Association of Certified Fraud Examiners, 2020). PricewaterhouseCoopers (PWC)'s Global Economic Crime and Fraud Survey (2020) documented that the accumulated cost of financial crime is USD\$ 42 billion. The ongoing fraud scandal of 1MDB has proved that corporate scandals still exist. During the pandemic of Covid-19, many big companies are facing financial difficulties and some of them had to restructure their companies such as reducing the number of employees and closing down some branches. Therefore, the performance of companies will be affected by this corporate failure.

The aim of this study is to determine the effect of fraudulent activities on the corporate performance of Malaysian companies in the tourism sector from the year 2017 until 2020. The panel effects model is applied since the data contains observations on different companies' sections across time and to cater the endogeneity problem. We found a negative significant effect of corporate fraud on the Malaysian listed firm performance for both the accounting and market measures. The results supported the agency theory, which suggests the existence of conflict of interest in the companies.

The current findings served as indications to the company as they can strengthen their management processes to fight fraud and to improve firm performance. Second, this study will also shed a light on investors in understanding what is happening to the company in which they have largely invested if it caught up with fraud. Finally, on the academic side, this study will contribute towards literature relating corporate fraud to academic researchers studying fraud management in Malaysia.

\section{Literature Review}

Despite the numerous number of mechanisms to mitigate the occurrences of corporate fraud, there is still quite of several cases that occurred especially when the world has still faced the pandemic Covid-19. In Malaysia, most of the companies especially in the tourism sector are facing difficulties to sustain in the industry. Tourism is vital for the success of many economies around the world. The severe outbreak of the pandemic has demanded the country to implement the Movement Control Order or MCO to stem the increasing number of COVID-19 cases in Malaysia (Mustapha \& Mohamad, 2021). However, the restricted movement and closed borders have negatively impacted the country's tourism industry. As a people-oriented industry, tourism is one of the hardest-hit economic sectors. Due to that, they had financial constraints in sustaining their business. Many employees have lost their jobs and become unemployed (Khanna, 2020).

Some hospitality companies such as hotels and tourism companies were among the most victims due to the pandemic. In Malaysia, some top hotels have closed their operations as they were unable to sustain in the industry. This is not only affected the companies but also the Government of Malaysia as Malaysia was promoting the Year 2020 Visit Malaysia. Not only that, the effects of this pandemic also resulted in losses of hundreds of millions of ringgits to the government. The national currency has also fallen to the level of USD1 equivalent to RM4.20 since the economic downturn in 1997. 
Malaysia has become one of the tourist attractions from abroad to visit (Cham, Lim, Siah, Cheah \& Ting, 2021). With an equatorial climate and a multi-racial and multi-religious society, Malaysia is one of the countries in the world known for its natural attractions. According to the Ministry of Tourism, Arts and Culture Malaysia Malaysia, foreign tourist arrivals into the country are in the range of 24 million to 27 million from 2011 to 2019. This shows that the average arrival for these 9 years is as much as 25.92 million (Ministry of Tourism, Arts and Culture Malaysia, 2021). However, at the end of 2019, the world was shaken by the spread of the life-threatening Covid-19 virus. The virus originated from Wuhan Province in China. This saw a decline in the rate of entry of foreign tourists into the country in the following year.

The year 2020 saw only 4.33 million foreign tourist arrivals. This is far from the average foreign tourist arrivals for the previous 9 years. This amount not only worries the government as the country's revenue is declining, but it also has a huge impact on the tourism industry players in the country. Many tour operators had to bear the brunt of the pandemic. In fact, many employers have had to lay off their employees and the country's unemployment rate has also risen. This is of great concern to all parties and the year 2020 will see the collapse of many small and medium companies in Malaysia. Figure 1 shows the tabulation of tourist arrivals to Malaysia.

Figure 1. Tourist Arrivals to Malaysia from 2011-2020

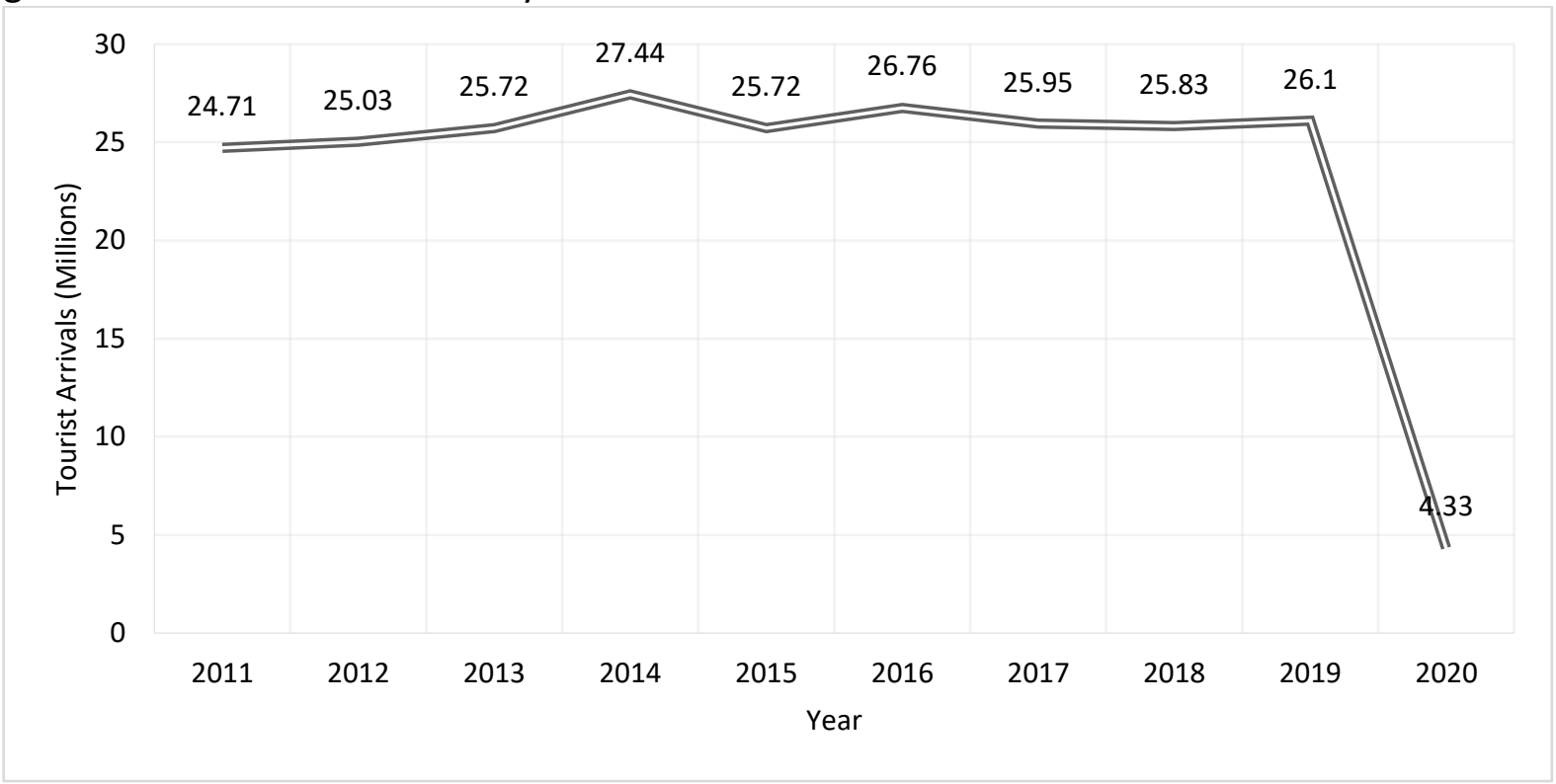

Source: Ministry of Tourism, Arts and Culture Malaysia

On the other note, the income from tourism sector also 
Figure 2. Receipts to Malaysia by Year

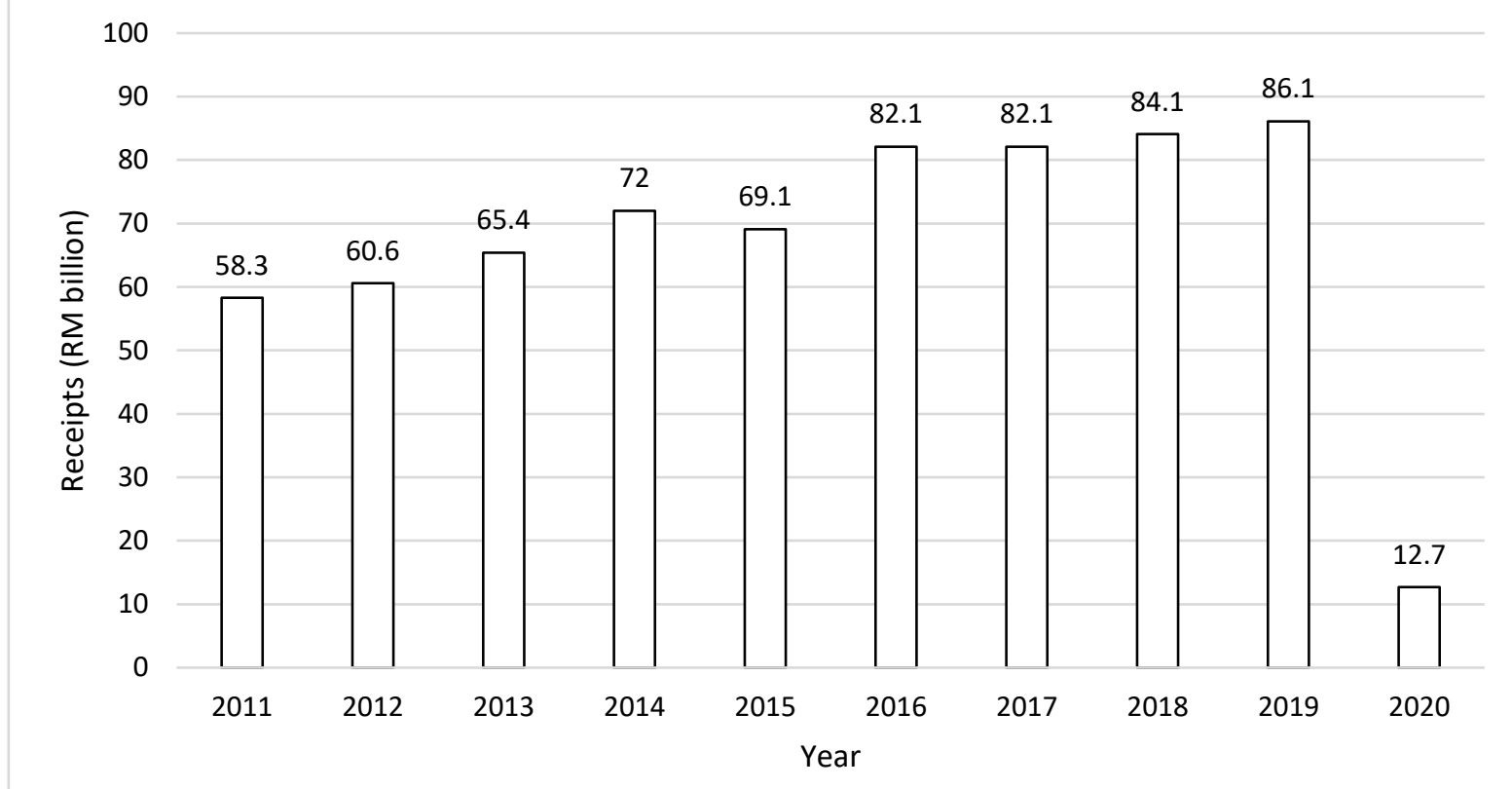

The year 2020 is also known as 'dark year' for all countries in the world. This year is the beginning of a fall in world stock prices and many people are losing their jobs. This is compounded by the announcement by the government to implement the movement control order (MCO 1.0) which took effect on March 18, 2020 (News Strait Times, 2020). To date, Malaysia has implemented three movement control orders and certain localities have been subject to tightened movement control orders. This has hampered movement across districts and states and the tourism sector has been severely affected by the current situation.

This research is using the Agency Theory to determine the effect of corporate fraud on firm performance. Past studies have suggested the existence of conflict of interest in the companies with fraudulent activities. In the ambit of financial management, this relationship arises between self-interested managers and shareholders. Shareholders are supposed to be only concerned with the value of their investment. However, conflict arises when opportunistic managers engage in decision-making and behaviors that tend to benefit directors as controlling that would eventually result in a lower quality of reported earnings (Gonzalez \& Garcia-Meca, 2014). However, it is contrasted a study by Wang \& Demer (2010) where they found the corporate fraud may increase the firm performance.

Therefore, this study hypothesized that:

H1: There is a negative association between corporate fraud and corporate performance.

The specific hypotheses are:

H1a: There is a negative relationship between corporate fraud and Tobin's Q.

$H 1 b$ : There is a negative relationship between corporate fraud and Return of Asset (ROA). H1c: There is a negative relationship between corporate fraud and Return on Equity (ROE). 


\section{Research Methodology}

This research employs methodology that was mostly used in previous studies to proof the hypotheses. The methodology is separated into three-part, (1) fraud determination using Beneish's Model, (2) performance determination using market and accounting measures, and (3) pool effect model for the regression model.

\section{Sample}

This research uses data for the leisure and hospitality sector in Bursa Malaysia Berhad (BMB) which was taken from the DataStream Thomson Reuters and annual report. It covers the period of 2017 - 2020. This is to view the trend of corporate fraud towards the performance of these companies in Tourism sector for 4 years. Other than that, this study also trying to determine the effect of corporate fraud in 3 years prior to the pandemic of Covid-19 and 1 year during the pandemic is still around. Initially, there are 29 companies listed under the leisure and hospitality sector in BMB. The final sample for firm-year observations is 81 . This study will be divided into two categories; 1) pre-from 2017 until 2019 and 2) During in 2020.

\section{Variables}

The extent of potential fraudulent companies was measured using Beneish M-score Model. As pointed out by Ezrein, Md Salleh, and Ahmad (2016), this model can detect $82 \%$ of the public listed companies prosecuted for fraudulent financial reporting by the Securities Commission of Malaysia, hence providing evidence that this model is reliable and capable of identifying potential fraudulent companies listed in BMB. This model uses eight financial ratios to detect financial statement fraud which can be explained in Table 1 . The summary of variables is shown in Table 1.

The eight variables of Beneish $\mathrm{M}$-score will be calculated using the following formula:

$\mathrm{M}=-4.84+0.92 * \mathrm{DSRI}+0.528 * \mathrm{GMI}+0.404 * \mathrm{AQI}+0.892 * \mathrm{SGI}+0.115 * \mathrm{DEPI}-0.172 * \mathrm{SGAI}+$ $4.679 *$ TATA $-0.327 *$ LVGI

The $\mathrm{M}$ score is the figure derived from the model. M-score of less than -2.22 indicates that a company does not manipulate the financial statement in the accounting period. M-score greater than -2.22 signals that the company will likely be a manipulator. These parameters are calculated from data available in company financial reports. Therefore, using this model, the companies that likely manipulate financial statements can be determined. The score of " 1 " will be given if the companies had red flags indicating that there are possibility of fraudulent financial statements and " 0 " if otherwise.

SIZE is calculated by the natural logarithm of total assets and GROWTH is measured by company's market value at year-end divided by the book value of total assets or sometimes referred to as market-to-book value (MTB).

Previous studies had different views on the relationship between company's size and corporate performance, and these views can be simplified in threes. First, there is a connection between internal control mechanisms and the company's size; in which the company's size would be bigger when there is high internal control mechanisms (Ali et al., 2015). Second, most 
companies rely on reputable auditing firms to enhance corporate performance (Ali et al., 2015). Third, large companies have more funds to leverage the best technology and expertise to present financial information to the masses. As such, they are improving their performance than small companies as they see their reputation and cost in the form of financial analysts. In large boards, they employ a sophisticated system of internal controls and are audited by high-quality auditors (Habib et al., 2017).

Similarly, a past study has found a significant association between firm size and EM practices (Al-Ajmi, 2008). The study documented that the larger the company, the lower their EM practices will be. This relationship will enhance the company's performance as company size is related to low agency issues. Because of effective governance practices, larger companies tend to be better in terms of management processes and transparency which will propagate the earnings efficiency (Marra et al., 2011).

In contrast, previous research has indicated that large companies are more likely to release earnings reports than small companies due to external pressure (Abbott, Parker, \& Peters, 2012; Baatwah, Salleh, \& Ahmad, 2015; Sharma, Tanyi, \& Litt, 2017). On a similar note, different views indicate that larger companies tend to manage more earnings than smaller companies due to the pressure from investors and to meet analysts' expectations (Mishina, Dykes, Block, \& Pollock, 2010). Larger companies also have more accounting treatment for transactions which allows them to manage their earnings from small companies. Furthermore, larger companies are driven to manage their earnings to reduce political costs. The benefits and skills of organising earnings are dependent on the size of the company (Ali et al., 2015). Based on the above discussion, this study is expected to have a positive relationship between a company's size and performance.

The regression model in this study is:

Performance: $\alpha_{0}+\beta 1$ Beneish $+\beta 2$ SIZE $+\beta 3$ GROWTH $+\beta 3$ LEVERAGE $+\varepsilon_{i t}$

\section{Data Analysis}

\section{Data Screening}

The process of data screening, regardless of the type of analysis, was implemented meticulously with added precaution (Cooke, 1998). In this process, any normality problems could be detected, which can lead to issues of outliers and non-linearity. Consequently, in ensuring the validity of data, the collected data were screened before being subjected to further analysis.

\section{Missing Data}

In statistics, there could be an incidence of missing data. This is a situation where one or more variables are missing from the data set, or invalid values are stored (Hair, Black, Babin, Anderson, \& Tatham, 2010). Sample size may shrink due to missing data. Therefore, missing data could lead to inaccurate and biased results. (Hair et al., 2010). Before further analysis, the missing value study is checked for each variable.

\section{Outliers}

There are several options to minimise the impact of outliers, such as discarding cases where there is an appropriate justification that they are not part of the population, changing data, or changing 
scores (Field, 2009; Tabachnick et al., 2007). Therefore, the presence of data for each of the variables in this study was tested before further analysis. This study used Cook's Distance Test to detect any extreme outliers (Cook, 1977).

\section{Normality}

The rule of thumb is the range of skewness and kurtosis in social science research must be within \pm 2 (George \& Mallery, 2003; Gravetter, Wallnau, Forzano, \& Witnauer, 2020; Hair et al., 2010). Theoretically, if the data sets are normally distributed, the skew of asymmetric distribution will be zero. Nevertheless, this is very unlikely for an actual situation. As such, some value of skewness is usually expected. The value of skewness can be either positive or negative. Positive skewness indicates that the distribution of the data is clustered to the left and vice versa (Pallant, 2010).

\section{Results}

\section{Descriptive Statistics}

Based on Table 2, the descriptive statistics in this study is consistent with previous studies done by Gonzalez \& Garcia-Meca (2014) and Ezrein et al. (2016). The mean for Beneish is -2.460797, which indicates that the sample of companies in this study does not manipulate the financial statement in the accounting period. While the data is normally distributed even some of it is out of the range of -2 and 2 . This is because the sample of observations is minimal.

\section{Regression}

This study found a mixed finding based on the regression results. For pooled data, only ROE is positively significant at $1 \%(\mathrm{t}$-value $=2.97)$. This indicates that corporate fraud may not be deteriorating the performance of the company through shareholders' equity. Meanwhile, other variables are not significant. Therefore, this study has not supported all hypotheses. For presamples, the same result was also acquired with a positive significant relationship with ROE at $1 \%$ (t-value= 4.45). Hence, no hypotheses are supported. However, during the pandemic, there is no significant results were found. This could be due to the number of samples which is low and the effect cannot be determined only for one year. The result of the regression can be seen in Table 3.

\section{Discussion}

Overall, this empirical analysis of Malaysia's tourism sector provides broadly consistent outcomes with those reported by Jawabreh, Bader, Saleh and Alrabei (2018). The results have proved the insignificant relevancy of Agency Theory in determining the effect of corporate fraud on firm performance. This proved that some companies are not engaged in corporate fraud, hence, they do not deteriorate the firm performance (Wang and Demer, 2010). This can be added to the reports made by the BMB in which some companies in this sector are having financial difficulty or even already went for bankruptcy. That could be one of the reasons in this study which has found an insignificant relationship with performance.

\section{Conclusion}

The aim of this research is to determine the impact of corporate fraud on corporate performance in the tourism sector in Malaysia, with a detail assessment on pre and during the Covid-19 
pandemic. The data was covered from year 2017 until 2020.This research found supporting evidence on the effect of corporate fraud on firm performance, where it is related to the agency theory. When a company is involved in fraudulent activities, it would increase the performance of the company, only through ROE. This, in turn, would not affect the reputation of the company and the trust stakeholders have put in will not deteriorate. Nevertheless, this unethical behaviour might affect the company performance in a long run.

On July 2021, The Ministry of Tourism, Arts and Culture Malaysia (MOTAC) has welcomed the proposal from the Malaysian Association of Theme Park and Family Attractions (MATFA) on the action that can be taken by the Government of Malaysia. This is to ensure the viability of the tourism industries core businesses such as Theme Parks, Attractions, Playland, SPA Wellness, Cinema and Family Entertainment Centers. MOTAC would like to reiterate Government's commitment in ensuring the tourism industry stays afloat with well prepared and programs. With the aim to revive the economy and to ensure the continuity of businesses while retaining the employment of thousands of workers, especially Malaysians, the Government has unveiled several economic stimulus packages such as PEMULIH, PEMERKASA Plus and PEMERKASA. With these initiatives by the Government, it is hoped that it can help revive the country's tourism sector and become one of the sources of income for the country.

As similar to previous research, there were several weaknesses found in this study. This is a preliminary study to determine the extent of the impact of the Covid-19 pandemic on corporate performance, especially in the tourism sector. The tourism sector is one of the sectors most affected by the pandemic. Nevertheless, the results from this study cannot be generalised to all public listed companies in Malaysia. This is because each sector might have different impact from the pandemic.

To overcome the constraints, present in this study, several things can be considered for future studies. Further analysis can be done on the effect of corporate fraud on companies during and after the pandemic is over. A larger sample is also required to generalise the findings not only to one sector but to all public listed companies.

\section{Acknowledgement}

We would like to thank the Accounting Research Institute HICOE and the Research Management Institute (RMI), Universiti Teknologi MARA (UiTM), and Malaysian Ministry of Higher Education for providing financial support for this research.

\section{References}

Beneish, M. D. (1997). Detecting GAAP violation: Implications for assessing earnings management among firms with extreme financial performance. Journal of accounting and public policy, 16(3), 271-309.

Beneish, M. D. (1999). The detection of earnings manipulation. Financial Analysts Journal, 55(5), 24-36.

Cham, T. H., Lim, Y. M., Sia, B. C., Cheah, J. H., \& Ting, H. (2021). Medical tourism destination image and its relationship with the intention to revisit: A study of Chinese medical tourists in Malaysia. Journal of China Tourism Research, 17(2), 163-191.

Ezrein, M. K. M., Salleh, M. F., \& Ahmad, A. (2016). Detecting Financial Statement Fraud by Malaysian Public Listed Companies: The Reliability of the Beneish M-Score Model 
(Mengesan Penipuan Penyata Kewangan oleh Syarikat Tersenarai di Bursa Malaysia: Keberkesanan Model Beneish M-Score). Jurnal Pengurusan, 46, 23-32.

González, J. S., \& García-Meca, E. (2014). Does corporate governance influence earnings management in Latin American markets? Journal of business ethics, 121(3), 419-440.

Ministry of Tourism, Arts and Culture Malaysia (2020). https://www.tourism.gov.my/ statistics. Retrieved on 20 August 2021.

Jawabreh, O., Bader, A., Saleh, M., \& Alrabei, A. M. A. (2018). Fraud Inference Investigation within Tourism Sector in Jordan. Journal of Economic \& Management Perspectives, 12(1), 5-20.

Khanna, A. (2020). Impact of migration of labour force due to global COVID-19 pandemic with reference to India. Journal of Health management, 22(2), 181-191.

KPMG Malaysia Fraud, Bribery and Corruption Survey (2013). Retrieved on 30 June 2021.

Mustapa, A. N., \& Mohamad, A. (2021). Malaysian Government Business Support and Assistance for Small and Medium Enterprises: A Case of COVID-19 Pandemic Crisis. In Modeling Economic Growth in Contemporary Malaysia. Emerald Publishing Limited, Bingley, 291-305.

Nasir, N. A. M., \& Hashim, H. A. (2020). Corporate governance performance and financial statement fraud: evidence from Malaysia. Journal of Financial Crime.

News Strait Times. (2020). https://www.nst.com.my/news/nation/2021/07/706898/revert-mco10-mode-experts-urge. Retrieved on 20 August 2021.

PricewaterhouseCoopers (PWC)'s Global Economic Crime and Fraud Survey (2020). Retrieved on 30 June 2021.

Wang, C., \& Demers, E. A. (2010). The Impact of CEO Career Concerns on Accruals Based and Real Earnings Management. Ssrn, (November). 
INTERNATIONAL JOURNAL OF ACADEMIC RESEARCH ECONOMICS AND MANAGEMENT SCIENCES Vol. 11, No. 1, 2022, E-ISSN: 2226-3624 (C) 2022 HRMARS

\section{Appendices}

Table 1: Description of Variable used in this research

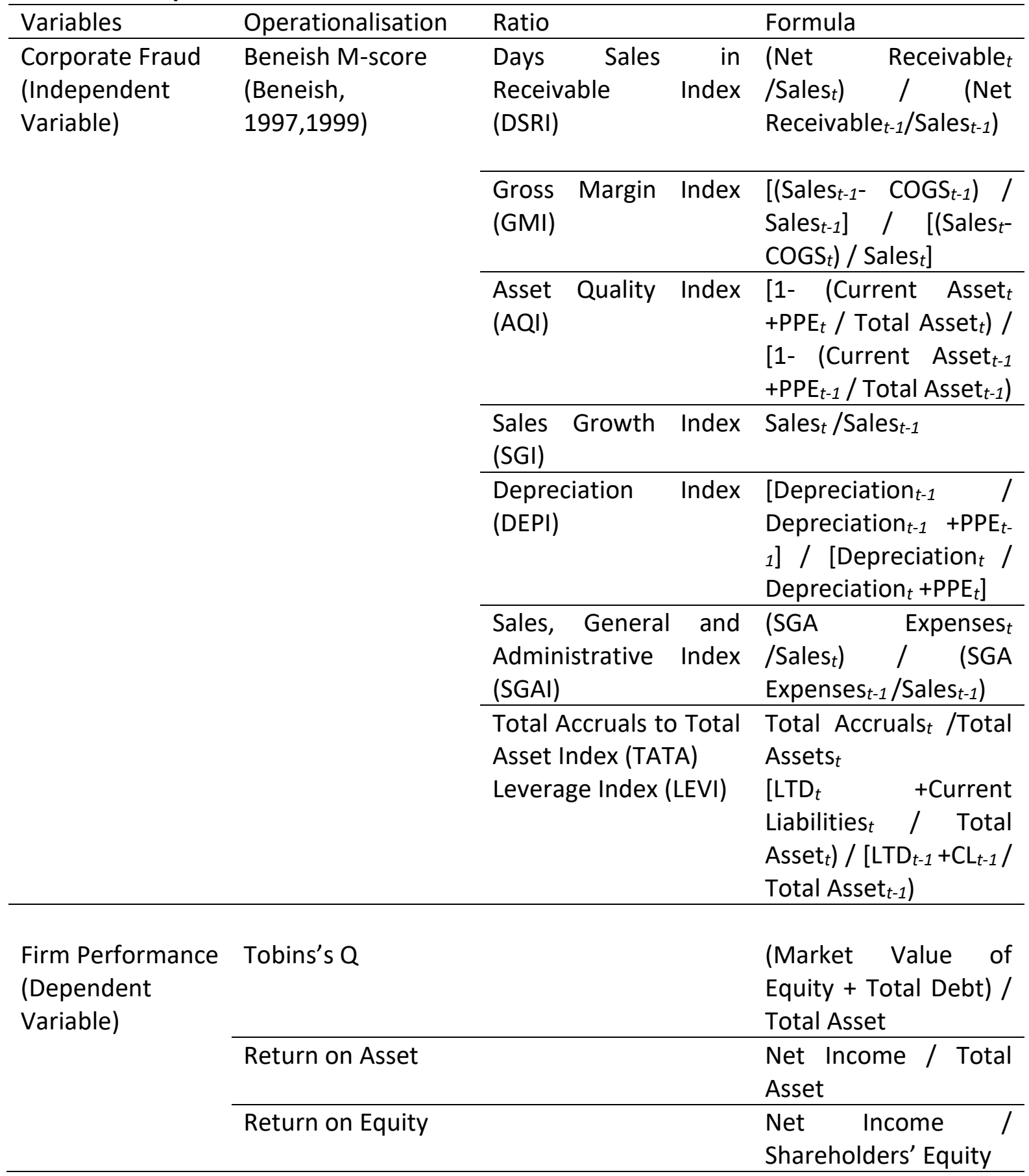


INTERNATIONAL JOURNAL OF ACADEMIC RESEARCH ECONOMICS AND MANAGEMENT SCIENCES Vol. 11, No. 1, 2022, E-ISSN: 2226-3624 @ 2022 HRMARS

Table 2: Descriptive Statistics

\begin{tabular}{lllllll}
\hline & Min & Max & Mean & Std. Dev & Skewness & Kurtosis \\
\hline Beneish & 0 & 1 & 0.654032 & .8024001 & 1.607963 & 7.224678 \\
TobinsQ & .0003522 & 2.906427 & .4867534 & .5824037 & 2.304168 & 8.062548 \\
ROA & .0165337 & 5.247029 & .5439257 & .8222358 & 4.196424 & 2.1964 \\
ROE & -3.050011 & 108.0669 & 2.259265 & 10.55693 & 9.204314 & 9.137765 \\
SIZE & 4.310247 & 8.007068 & 5.824701 & .8495092 & .4981543 & 2.931115 \\
GROWTH & .0000587 & 2.202865 & .2106615 & .4877316 & 2.432294 & 8.058973 \\
\hline
\end{tabular}

Table 3: Regression Results on Corporate Fraud

\begin{tabular}{|c|c|c|c|}
\hline & Pooled & Pre & During \\
\hline \multirow[t]{2}{*}{ Constant } & -1.955887 & -.281026 & -.1607307 \\
\hline & $(-2.79) * * *$ & $(-5.17) * * *$ & $(-0.85) * * *$ \\
\hline \multirow[t]{2}{*}{ TobinsQ } & -.267113 & -.4664326 & -.2579309 \\
\hline & $(-0.39)$ & $(-0.81)$ & $(-0.15)$ \\
\hline \multirow[t]{2}{*}{ ROA } & -.1099054 & -.073733 & 1.019492 \\
\hline & $(-0.91)$ & $(-0.92)$ & $(0.78)$ \\
\hline \multirow[t]{2}{*}{ ROE } & .0802568 & .0820168 & -.2266167 \\
\hline & $(2.97) * * *$ & $(4.45) * * *$ & $(-0.76)$ \\
\hline \multirow[t]{2}{*}{ SIZE } & -.0418454 & .0336564 & -.1389129 \\
\hline & $(-0.35)$ & $(0.718)$ & $(-0.43)$ \\
\hline \multirow[t]{2}{*}{ GROWTH } & .4281768 & .4960728 & 6041579 \\
\hline & $(0.51)$ & $(0.70)$ & $(0.29)$ \\
\hline \multirow[t]{2}{*}{2018} & -.3727356 & .0854619 & - \\
\hline & $(-1.53)$ & (0.59) & \\
\hline \multirow[t]{2}{*}{2019} & -.467493 & .2065347 & - \\
\hline & $(-1.97)$ & $(0.48)$ & \\
\hline \multirow[t]{2}{*}{2020} & -.9410168 & - & - \\
\hline & $(-.858)$ & & \\
\hline Firm Effect & YES & YES & YES \\
\hline Year Effect & YES & YES & - \\
\hline R Squared & .1695 & .3813 & .1813 \\
\hline Adjusted R Squared & .0742 & .2885 & .0999 \\
\hline F-stat & .1079 & .0026 & 0.8713 \\
\hline $\mathrm{N}$ & 81 & 57 & 24 \\
\hline
\end{tabular}

***Significant at the $1 \%$ level (1-tailed), **Significant at the $5 \%$ level (1-tailed), *Significant at the $10 \%$ level (1-tailed) 